\title{
Koraszülés, karantén, családok: Koraszülésben érintett családok közösségi támogatásának online lehetőségei a Covid-19-járvány idején
}

Preterm birth, quarantine, families: Preterm birth families' supporting possibilities during COVID-19 pandemic by communitybased telemedicine methods

\section{FARKAS ATTILA}

Farkas Attila: Korábban Érkeztem Alapítvány (Szeged); farkas.attesz@ gmail.com Attila Farkas: Early Arrival Foundation (Szeged, Hungary); farkas.attesz@gmail.com

\begin{abstract}
Absztrakt
A Covid-19-járvány izolációval járó társadalmi krízis. Csökkenti a természetes támogatási lehetőségeket az egyén, a család és a közösség között. A koraszülés komplex, az egész család krízismátrixából eredő ellátást-támogatást kívánó állapot. Ebben az összetett helyzetben az ellátást a Korábban Érkeztem Alapítvány online módon biztosítja a koraszülésben érintetteknek. Sérülékenységük okán célcsoportként megjelennek az apák is. Az online átállás hozadékai, hogy a szolgáltatások, a közösségi kapcsolódás jól müködik, de tudatosan kell kezelni a rizikófaktorokat, és szemlélettágítást követel a szakmai közegtől is.
\end{abstract}

Kulcsszavak: koraszülés, krízis, mentálhigiénés támogatás, közösség, e-mentálhigiéné

\begin{abstract}
This paper examines the impact of the COVID-19 pandemic on premature birth and its care. The COVID-19 pandemic is a social crisis involving personal isolation, and delimiting natural forms of support between individuals, families and communities. Premature birth is a complex situation causing a crisis for the mother and the family and it has emerging care needs. The Korábban Érkeztem Alapitvány (Early Arrival Foundation) is providing care via online platforms for this situation. Preterm babies' fathers are also a vulnerable group who utilize these services. Transferring care to online platforms has some benefits, such as operable telehealth/telecare services and e-community connections. However, the situation requires systemic risk management and a more open and flexible approach on the part of the professionals concerned.
\end{abstract}

Keywords: preterm birth, crisis, mental health support, community, telehealth

\section{Bevezetés}

A Korábban Érkeztem Alapítvány (a továbbiakban: KÉA) küldetésében a koraszülésben érintett családok támogatását határozza meg elsődleges célként. E célkitüzésnek adott keretet az EFOP-1.2.10-16-2016-00002 azonosítószámú, Mentorházak és mentorhálózat kialakitása koraszülöttek és családjaik számára a Dél-Alföld Régióban címü projekt. Az Európai Unió 
támogatásával, az Európai Szociális Alap és Magyarország költségvetésének társfinanszírozásában valósul meg 100\%-os finanszírozottsággal 2017 és 2020 között.

Az alábbi tanulmány célja, hogy bemutassa, milyen közösségi és egyéb támogatásiellátási formákat dolgozott ki a KÉA (más, korábban ilyen formában be nem vezetett szolgáltatások mellett) annak érdekében, hogy a koraszülésben érintett családok támogatása megvalósulhasson. Röviden bemutatjuk, hogy az életet hazánkban is felforgató járvány hatásaira-kihívásaira milyen, az online világban megvalósuló válaszokat adtunk, és ezeket hogyan értékelhetjük az elmúlt három hónap tapasztalatainak fényében.

A jelenlegi helyzet rövid áttekintését követően egymással összefüggö területeként röviden ismertetjük:

- a koraszülés legfontosabb jellemzőit,

- a közösség szerepét a megküzdésben és a mentálhigiénés támogatásban,

- a létrejött támogató-, illetve ellátást nyújtó fórumokat és ezek online térre történő átállásának legfontosabb tapasztalatait;

- mindezek mellett kitérünk az apákra mint külön célcsoportra is.

\section{A karanténhelyzet mint társadalmi-családi krízis}

A WHO 2020 januárjában a koronavírus-járványt nemzetközi szinten aggodalomra okot adó közegészségügyi helyzetként értékelte, majd márciusban világjárványnak minősítette (World Health Organization, 2020). Közleményében több helyen említi a közösségen belüli kölcsönös támogatás, a pozitív példák, a körültekintő informálódás szerepét, ami összhangban áll törekvéseinkkel, miszerint a közösség megtartó erővel szolgálhat tagjai számára.

A Covid-19-járvány globálisan elfogadott menedzselési stratégiájává a vírus terjedését kezelhető szintre lassító szociális izoláció vált. Ennek velejárója azonban a családi, baráti, munkahelyi és egyéb fontos kapcsolatok jelentős beszükülése (Zhou és mtsai., 2020), és így a velük járó pszichológiai-instrumentális javakhoz való hozzájutás is akadályozott. E hiány mentálhigiénés jelentősége nyilvánvaló: azok a természetes közösségi támogatórendszerek, amelyek különösen krízis idején tudnak hathatós támogatást nyújtani, csak nagyon korlátozottan érhetők el. Mindezek miatt a tág értelemben vett, akár szubklinikus formát öltő szorongással összefüggő mentális- és viselkedészavarok is felerősödhetnek. Zhou és munkatársai (2020) szerint ebben a helyzetben jelenik meg igazán az e-mentálhigiéné ${ }^{1}$ jelentősége, amely hozzájárulhat a pszichológiai jóllét fenntartásához. Különféle formái részben kognitív szinten hatnak, ám kiemelendő, hogy az online önsegítés lehetőségét biztosító felületek a hangulati élet és a szorongás területeire céloznak (Zhou és mtsai., 2020).

A kialakult helyzet egyértelműen társadalmi szintű krízisként értékelhető. A társadalmi krízis jellemzője, hogy átfogóan érinti a teljes népességet, az addigi, biztonságot nyújtó normák fellazulnak. Megnövelik a népességben a szorongást, a félelmet, és ennek folyamata sokaknál különféle szorongással, stresszel összefüggő, életminőséget negatívan érintő tüneteket is előidézhet. Hatása nem csupán társadalmi, vagy egyéni léptékü, hanem a családok esetében is számottevő, mégpedig horizontális és vertikális metszetben egyaránt (Hajduska, 2010). A családok életére gyakorolt hatása alapján Minuchin (2005) fogalmi rendszerét értelmezési

\footnotetext{
${ }^{1}$ Saját fordítás a „telehealth” vagy „mhealth” („,mobile health”) szóból, amely prevenciót, ellátást is jelent. A hivatkozott cikkben a szerzők a mentális egészséghez kapcsolódó szolgáltatások kontextusában használják.
} 
keretként használva megállapíthatjuk, hogy a jelenlegi Covid-19-járványhoz köthető helyzet (továbbiakban: karanténhelyzet) a családot közelről érintő pszichoszociális stresszor. A szerző négy alakzatát különbözteti meg a család alkalmazkodását megkívánó helyzeteknek. Ezek közül jól leírja a társadalmi-családi-egyéni szinten zajló folyamatokat az a kategória, amelyet Minuchin így nevez: ,, a teljes család stresszes kontaktusa extrafamiliáris erökkel” (Minuchin, 2005: 64). A szerző támogatási lehetőségként tekint, és külön hangsúlyt helyez a család és a közösségek összekapcsolásának elősegítésére.

Egy társadalmi léptékü válság következményei generációkon át kifejtik hatásukat. Ennek illusztrálására Bowen (idézi Goldenberg \& Goldenberg, 2008) transzgenerációs megközelítése kínál adekvát formát. Két, egymással szorosan összefüggő elméleti magyarázó fogalma különösen aktuális: az elkülönülés és az ún. társadalmi regresszió. Az elkülönülés sok más nagynevü szerző megállapításaihoz hasonlóan a pszichológiailag érett személyiséget írja le. Jellemzője, hogy képes egyensúlyban tartani a kognitív és az érzelmi müködését. Így egyszerre lesz önmagában teljes személy, aki ugyanakkor éppen ezért (egyfajta tudatos érzelemszabályozásából következően) képes intimitást is kialakítani a kapcsolataiban. Ezt a fajta önirányítási képességét stresszhatás alatt is képes megtartani.

A társadalmi regresszió lényege, hogy a családhoz hasonlóan a társadalomban is megjelenik az egybeolvadás és a különállás ellentétéből fakadó szorongás. Ha a társadalmi légkör maga is szorongó, felerősödik, és az egybeolvadás felé hat, mivel a differenciáltság ellenében a kevésbé tudatos múködés felé tolja az egyéneket, családokat, így mentális egészségüket veszélyezteti.

Az egyéni-családi adaptív viselkedés fenntartásának kérdései különösen hangsúlyosak az olyan társadalmi szintü krízis idején, amilyen a jelenlegi karanténhelyzet.

\section{A koraszülés és jelentősége: családi és egyéni válság}

Hazánkban a koraszülések (37. gesztációs hét elött bekövetkező szülések) aránya 8-10\% között mozog (Aszmann, 2006). Hatásai rendkívül komplexek és sok tényező által befolyásoltak. A teljesség igénye nélkül néhány fontos területet röviden ismertetünk, s közben az apákra mint külön célcsoportra is fókuszálunk.

Maga a koraszülés többszörös krízishelyzetet teremt, hiszen az egyén (Erikson, 1997) és a család is fejlődése során ún. fejlődési krízisek útján lép át egyik életszakaszból a másikba (Hajduska, 2010). A koraszülés a normatív, fejlődési krízisek és az akcidentális krízisek kombinációja, ezért egyértelmúen krízismátrix alakul ki (Jacobson, 1979). A krízis kimenetele meghatározza a későbbi életszakaszok minőségét, a társas támogatás pedig nagymértékben befolyásolhatja, hogy adaptív irányba lehet-e továbblépni belőle. Ahogyan erről a későbbiekben lesz szó, a közösségek rendkívül értékes szerepet játszhatnak a konstruktív folytatásban.

A gyermekvárás örömmel és szorongással kísért készülődése segíti az előzetes hangolódást a szülői szerepre, az egyéni és kapcsolati változásokra (Komlósi, 1997). Ennek hirtelen és sokkoló módon szakad vége, ami tapasztalatunk szerint a legtöbb esetben krízist és/vagy traumatizációt okoz. Hosszú ideig kérdés marad, hogy érinti-e a gyermek fejlődését, mennyire és milyen formában. Ha a szülőknek korai élettörténeti elakadásai vannak (korai traumák, kötődési nehezítettségek a saját szüleikkel), ilyenkor aktiválódnak, és tovább komplikálják a helyzetet. 
A koraszülés az éppen szülővé váló pár és a család életében olyan válságállapot, amely elemi hatású, és igen gyakran hosszan fennálló stresszt jelent a szülők számára (Patil, 2014). A legtöbb esetben a koraszülött gyermek látványa, a szélsőséges bizonytalanság és a valós, valamint a fenyegető veszteség jellemzi a koraszülés első időszakát (Monostori, 2020). E hatások talaján kialakulhatnak betolakodó emlékek, alacsony fekvésü hangulati állapotok, szorongásos állapotok, a stresszorral összefüggő ingerek elkerülésére tett kísérletek. Így szubklinikus vagy klinikus formában akut stresszreakció, poszttraumás stressz zavar is létrejöhet (American Psychiatric Association, 2014).

A párkapcsolat vagy magcsalád maga is mintegy „koraszülöttként”, a szükséges adaptációs időszak nélkül bővül (többgyermekes) családdá. McGrath (2001) megállapításait saját tapasztalataink is megerősítik. A szülők és a gyermek fizikálisan is szeparáltak egymástól. A szülök élményvilága így széttöredezetté válik, a szülői identitás sérül, és kötődési nehezítettségek jellemzik a helyzetet. A családi és egyéb természetes támogató kapcsolatok nagymérvű beszűkülésével párhuzamosan jellemző az orvosok és professzionális segítők felértékelődése (Dombi, Monostori \& B. Erdős 2019). Az anyák kompetenciaérzése nagymértékben lecsökken, büntudatérzésük jelentősen felerösödik. Valamennyi védettséget jelenthet, ha az anyának már van gyermeke, akivel kialakíthatta szülöi identitását (OlshtainMann \& Auslander, 2008). Mindezek mellett megjelennek a gyermek és édesanyja között a kötődési nehézségek, amelyek a helyzetből és a koraszülött baba éretlen idegrendszeri müködésből adódnak (Hámori, 2013).

A család szempontjából saját tapasztalataink jól magyarázhatók a strukturális, és részben a kontextuális családterápia alapvető konstrukcióival.

A családszerkezet (Minuchin, 2005) átalakulása komoly kihívásokat tartogat a szülők számára. A család külső határai ebben a helyzetben extrém módon megnyílnak, hiszen a gyermek nem a saját családjának közösségében kezdi az életet, hanem egy intézményben. A család funkcionális zártsága, amely az újrarendeződést, összehangolódást szolgálná, csak rendkívüli nehézségek árán, és időben nagymértékben elnyúlva tud megvalósulni. Kevés kivételtől eltekintve az anyák a PIC-en² töltik idejük nagy részét, míg az apák igyekeznek megosztani erőiket az anyagi biztonság fenntartása (munkavégzés) és az anyák, a család támogatása között. Így a szülői-végrehajtó alrendszer, amely a családi élet irányításának, védettségének alapvető biztosítását látja el, nagymértékben fragmentálódik.

A kontextuális családterápia (Boszormenyi-Nagy \& Spark, 2018) megközelítésében a gyermek alapvető, létezéséből eredő és megkérdőjelezhetetlen jogosultsága, hogy szülei gondoskodjanak róla. Ebből következően szüleinek egyszerre joga és kötelessége ezt megtenni, és ezzel mintegy a saját szüleitől kapott gondoskodást is továbbadni. A gyermek a gondoskodásért „,cserébe” elkötelezett lesz szüleinek, később pedig gyermekeinek adja maga is tovább a gondoskodást. Ez a folyamat alapvető rendje az emberi kapcsolatoknak. Így jön létre egy nemzedékeken átívelö egyensúlyozás jogok és kötelezettségek között, amely pszichológiai értelemben a család tagjaira nézve transzgenerációs szinten (is) meghatározó sorsformáló erő lehet. Koraszülés esetén a szülők joga és kötelessége, hogy közeledjenek gyermekükhöz, illetve gondoskodjanak róla, elveszti arányosságából eredő egyensúlyát. A koraszülés sajátos helyzetet teremt. Az egészségügyi ellátó intézmény az, akinek mintegy joga és kompetenciája a gyermek életben tartása és ellátása - arányaiban sokkal inkább, mint a szülőknek, akik bizonytalan idő

\footnotetext{
${ }^{2}$ A „PIC” (Perinatális Intenzív Centrum) kifejezés a koraszülöttek, újszülöttek intenzív ellátására szakosodott, sokrétü, magas felkészültséget igénylö, komplex és többszintủ gyógyító tevékenységnek otthont adó osztály(ok) rövidített és széles körben elterjedt rövidített elnevezése.
} 
után élhetnek ezekkel a jogokkal. Nem kis részben emiatt is élnek meg a szülök csökkent kompetenciaérzést. Mindez megnehezítheti a családon belül a jogok és elkötelezettség egyensúlyának fenntartását, így rendezetlen kapcsolati viszonyok maradhatnak vissza a családban, amelyek fokozzák a családtagok pszichológiai sérülékenységét.

\section{Az apák sérülékenysége}

Kopp, Székely és Skrabski (2007) kutatási beszámolójukban többek között a krónikus stressznek, a kontrollvesztés megélésének, a kiszámíthatatlanságnak tulajdonítják a férfiak korai halálozással kapcsolatos sebezhetőségét. Bár a szerzők szerint a férfiak magukat teszik felelőssé családjuk társadalmi-gazdasági helyzetéért, tapasztalatunk szerint ez a családjukkal kapcsolatos védelmező szerepre nézve is igaz. Úgy tapasztaljuk, hogy az apákra is hosszú távon hatnak a koraszüléssel kapcsolatos élmények, így még inkább rizikócsoportnak tekinthetők. Megszólításukat, bevonásukat így fontosnak tartottuk és tartjuk. Ennek érdekében megismerő jellegü kvalitatív kutatást végeztünk, amelyet folytatni szándékozunk (Farkas, Monostori, Rózsavölgyi, 2020). Eddigi eredményeink összecsengenek az alábbi külföldi kutatásokkal, ami megerősíti az apák támogatásának létjogosultságát.

Az apák koraszüléssel kapcsolatos élményeiben, viselkedésében megjelenik az érzelmi kivonódás a helyzetből és a kontrollálási törekvés a partner miatt (Hugill és mtsai., 2013). Ez egyfajta válasz lehet a megélt kontroll hiányára is, amely az információhiánnyal függhet össze. A helyzetet tovább komplikálja a belsővé tett szerep a család védelmezésével kapcsolatosan, aminek ebben a helyzetben nem tud eleget tenni (Arockiasamy, Holsti \& Albersheim, 2008). Az apák gyakran úgy érzik, az ismeretlenbe „dobták” őket, erre információkereséssel reagálnak, és az anya-gyermek védelmezőjének szerepét próbálják ellátni (Lindberg, Axelsson \& Öhrling, 2007).

Saját kutatásunk hasonló eredményeket mutatott. A várandósságban megjelennek a baljós előjelek. A váratlanul bekövetkező szülés folyamatából az apák kizáródnak, nincs kontrolljuk az események felett. A koraszülött gyermek látványa, akinek gépek és emberek küzdenek az életéért, ,és akkora, mint egy kukoricacső", ${ }^{3}$ az édesanyákhoz hasonlóan a Szanati Dóra által leírt „perceptuális sokkot” okozza náluk (Szanati, 2011: 190).

A koraszülés az apák számára is a véget érni nem akaró, diszfunkcionális átmenet helye, amikor a gyermekük már megszületett, de még nem érezhetik magukat apának. A család külső határai extrém módon megnyílnak, a szülői-házastársai alrendszer atomizálódik. Kiszolgáltatottság, kompetenciahiány és sodródás jellemzi ezt az időszakot. Az apák elbeszéléseiben sok esetben traumatizációra / akut stresszreakcióra utaló elem is megjelenik (American Psychiatric Association, 2013).

Összegzésként elmondhatjuk, hogy a koraszülés a szülőktől indulva akár több nemzedéket alapvetően és meghatározóan érintő, időben elhúzódó állapot. Átvészelésének módja és sikeressége, a felmerülő problémákkal történő megküzdés kimenetele minden érintett életminőségére nagymértékben hatást fog gyakorolni.

\footnotetext{
${ }^{3}$ Idézet egy apa elbeszéléséből.
} 


\section{Támogatási lehetőségek és az online átállás}

A koraszülés élményeinek feldolgozása, a szülői identitás meghatározása a karanténhelyzetben több szinten is nehezített. Társadalmi krízis alakult ki, amely izolációval jár, amit egyéni és családi szinten is komoly kihívások nehezítenek. Maga a koraszülés is krízismátrix. A krízis(ek) kimenetele döntő tényező a személy és a család életminőségére nézve. Ezt számos tényező befolyásolhatja, amelyeket tudatosan alakítva kedvező irányban érhetünk el változást. A KÉA küldetésével, céljaival összhangban elsődlegesen ezt, a szülők, és rajtuk keresztül a teljes családok hozzásegítését célozza a teljesebb élethez.

A hatékony támogatás kivitelezésében segíthet a szociális munka alapvető értékeként számontartott, és a pszichológiai ellátásban is egyre nagyobb szerephez jutó empowerment. Maga a fogalom egy-két szóban nehezen fordítható le magyarra. Nincs egyetlen egységes meghatározása, sok esetben a kliens képessé tételeként, illetve felhatalmazásként is fordítják. Szerepét is folyamatosan sok vita, értelmezési-szintetizálási törekvés kíséri (Masterson és Owen, 2006). Jelentésének minél pontosabb meghatározása mai napig szakmai diskurzusok témája a szociális és széleskörü értelemben vett egészségügyi ellátásokban. Jelen tanulmányban a következő értelemben használom a kifejezést: az egyén tudatos öngondoskodását célzó részvételének támogatása saját életének formálása céljából. Az empowerment szellemében az aktuális szükségletek mentén történő, minél nagyobb részvétel és kontroll elérését célzó támogatás jelenthet hatékony segítséget. A későbbiekben röviden ismertetjük ennek gyakorlati megvalósulását a KÉA munkájában.

A családok támogatásának több módja van, amelyeket három fô csoportba sorolhatunk. Ezek közül leginkább a harmadik, közösségi megközelítésre és ennek előnyeire fókuszálunk, amelyben szintén megjelenik az empowerment.

1) A család maga, mintegy „belülről”, saját erőforrásainak mozgósításával sikeresen alkalmazkodik a változást megkívánó helyzethez (Minuchin, 2005).

A koraszülésben érintett családok támogatása kapcsán saját tapasztalatunk, hogy minden család megpróbál alkalmazkodni a koraszüléshez, és ez a törekvés gyakran drasztikusan kimeríti erőforrásait. Ebben - az extrém gazdasági-, szociális- és pszichológiai megpróbáltatások mellett - szerepet játszik a család koraszülésből fakadó izolációja is, amely az apákat még inkább érinti.

2) Más esetekben a támogatás külső intézmények beavatkozása révén valósulhat meg ilyenkor azonban bizonyos esetekben különösen vékony lehet a határ a beavatkozás és a támogatás között, így az önállóság támogatása vagy a tanult tehetetlenség / függő helyzet kialakítása között.

Sokszor tapasztaljuk, hogy a PIC-et megjárt családok szembetünően nehezebben találnak rá saját szülői autonómiájukra, önállóságukra. Nagy különbséget kell áthidalniuk hazakerüléskor. Az intézményben eltöltött időszak alaposan strukturált, minden részletre kiterjedő szabályozottsága és a gyógyító személyzet állandó jelenléte biztonságot nyújt. Az otthonlét első napjaiban a várt megkönnyebbülés helyett az anyák és apák nagymértékü szorongást élnek meg. A szülőséggel járó felelősség és szabadság hirtelen kerül vissza hozzájuk, miközben kompetenciaérzetük csak lassan követi az eseményeket. Értékes lehetőséget jelentenek az olyan empowerment-jellegü kezdeményezésként felfogható törekvések, amelyek már a PIC-en is bevonják a szülőket az ellátásba. Ezek előnyös hatása a gyermek fejlődésére nézve igazolt (Vanderveen és mtsai., 2009). Ilyen pl. a KÉA projektje keretében Magyarországon is megvalósuló FINE-képzés (Family and Infant 
Neurodevelopmental Education; kb.: A Család és a Csecsemő Idegrendszeri Fejlődése Oktatóprogram) (Van der Pal és mtsai., 2007; Van der Pal és mtsai., 2008). A FINE-képzés kifejezetten a PIC-en dolgozó gyógyító személyzetnek nyújt többek közt új ápolásszemléleti megközelítést és a család nagyobb mértékü bevonását lehetővé tevő ellátási alternatívákat.

3) Harmadik forma a közösségek által nyújtott támogatások világa, amelyek a család belső, és a külvilág külső erőforrásait képesek mozgósítani és összekapcsolni. A közösségek szintjéhez sokban kapcsolódik a KÉA munkája is. Központi eleme a mentorkoncepció, amely új szolgáltatási formát igyekszik meghonosítani. Többek között együttmüködő sorstársi és professzionális segítést, támogató közösséget, élményfeldolgozást és képzést kínál. Megvalósulásában szupermentorok és mentorok vesznek részt. A szupermentorok képezik az első vonalat, akik képzésük és szakmai háttértámogatásuk révén elöször jelennek meg a koraszülött-ellátás különféle színterein. Ilyen módon összeköttetést hoznak létre az ellátók, a mentorok és a koraszülésben érintettek között. A második vonalban lévő mentorok így tervezetten és megfelelő háttérrel tudnak tevékenykedni a számukra megfelelő területen. Az Alapítvány lehetőséget biztosít az ún. mentorképzésre. A professzionális szakemberek által vezetett képzés kétnapos tematikus szülésélmény-feldolgozásból és egy egynapos önkéntes mentorálásra felkészítő napból áll. Ezt követően van mód háromalkalmas hospitálásra, majd visszajelzések után önkéntes munkára több, a koraszüléshez kapcsolódó területen.

Mindezek szorosan kapcsolódnak az Alapítvány küldetéséhez.

A KÉA Missziójának három alappillére közül a tanulmányunk szempontjából kettő releváns területet részletesebben is ismertetünk:

\section{A) Közösséghez tartozás lehetöségének biztositása a koraszülésben érintett családok számára a PIC-en töltött idöszak és a hazakerülést követöen is}

Alapvető kutatói megállapítás, hogy a koraszülésben érintett családok támogatását legalább egy éven át, nemcsak a PIC-ben, hanem otthon is javasolt fenntartani (Olshtain-Mann és Auslander, 2008). Ennek fóruma a Mentorközösség, amely a Dél-Alföldön élö koraszülöket tömöríti össze, a teljes létszám jelenleg 130 fö. A Mentorközösség rendszeres programjai a mentorklubok, amelyek a személyes találkozásra adnak lehetőséget. A mentorklubban ismeretségek és barátságok jönnek létre, a találkozások alkalmával tematikus alkalmak, beszélgetések, előadások és az igényekhez igazodó programok valósulnak meg. Formális és informális csatornákon keresztül hasznos információk, támogatás, a mindennapi élethez hasznos tippek vándorolnak a mentorok között. A mentorközösség nyíltan kimondott és mindenki által ismert írott és íratlan szabályai közül kiemeljük az alábbiakat:

- Mindenkinek joga van a saját fájdalmához és érzéseihez.

- Mindenki saját jogon értékes, egymást úgy fogadjuk el, ahogy vagyunk - egyet nem érteni lehet, de ez nem a másik személyét érinti, csak a véleménybeli különbséget.

- A Mentorközösségben mindenki egyenlö.

- Mindenki több a szerepeinél és saját szülőségénél: a teljes személyt szívesen látjuk.

- Összetartunk és vigyázunk egymásra, tiszteletben tartva a másik önállóságát.

\section{B) Sortárs segités önkéntesekkel és professzionális szakmai háttértámogatással}

A sorstárs segítés több színtéren történő aktivitást jelent, amely szerves része a közösségi életnek. A mentoroknak sorstársaik támogatásába, rendezvényeken való közremüködésbe, 
érzékenyítő alkalmakon történő közremüködésbe éppúgy van módjuk bevonódni, ahogy „,csak” jelen lenni a mentorklubokon, és élni a rendelkezésre álló lehetőségekkel. Minden mentorhoz tartozik egy szupermentor, aki kapcsolatot tart vele és kíséri, szükség esetén rendelkezésre áll.

\section{A támogató csoportosulások szerepe}

A támogató csoportok sokszor a maguk természetes müködése révén magától értetődő módon kapcsolódnak az egyének-családok életébe. Krízis idején, különösen a Covid-19-helyzet miatt kialakult szeparációs helyzetben jelentőségük felértékelődik. Áttekintésünket a Caplan és Killilea (1976) által „támogató rendszerü csoportosulásoknak” nevezett közösségek jellemzőinek segítségével folytatjuk. Tanulmányom céljával összhangban a jelenlegi helyzetben leginkább releváns közösségi vonásokat-funkciókat ismertetem. Kitérek arra is, hogy ezek hogyan valósulnak meg a koraszülöi támogatás egyik pillérét jelentő Mentorközösségben. Elöljáróban megállapítható, hogy a támogató csoportosulások az egyén saját problémamegoldó képességét facilitálják, ezáltal személyiségfejlődésében játszanak szerepet. A legfontosabb jellemzők közül hármat emelek ki, majd az összefoglalóban néhány fontos funkcióra is reflektálok.

A támogató csoportosulás jellegzetessége, hogy az egyént sajátos individuumként kezeli, az ö nyelvén beszél és személyes módon érdeklödik iránta

A mentornak az összetartozás érdekében nem szükséges önmagából, különbözőségéből feladnia, hanem önmaga maradhat akkor is, amikor az adott közösség támogatását veszi igénybe. Önazonossága révén tud hiteles támogatást nyújtani, a müködéshez hozzájárulni ő maga is.

A Mentorközösség íratlan szabálya: mindenkinek joga van a saját történetéhez és érzéseihez. Mindenkinek lehetősége van megélni és kifejezni saját negatív vagy pozitív érzéseit, függetlenül attól, hogy másnak mi a története. Mindenkinek a saját kihívásai a legnehezebbek, és saját örömei a legnagyobbak. Ez az alapelv sokat segít abban, hogy mindenki kapcsolatba kerülhessen saját feloldandó érzéseivel és saját erőforrásaival, és mindehhez kérhet, kaphat, és szabadon vissza is utasíthat bármilyen segítséget - ennélfogva saját jogosultságával is élhet élete irányítása kapcsán.

A sorstársakkal történő kapcsolat, a kölcsönös sorstársi támogatás sok területen bizonyította hatékonyságát. Tapasztalataink szerint a koraszüléshez kapcsolódó élmények oldódása gyakran éppen a párbeszéden keresztül valósul meg. A kölcsönös élménymegosztás jótékony hatású, a kreatív krízismegoldást, illetve a poszttraumás növekedést segíti elö. A közösség ellát bizonyos funkciókat is, amelyek a jellemzőkhöz hasonlóan az egyén önállóságának, megküzdésének gazdagítását hivatottak szolgálni. Egyértelmüen fontos az ellátás online térben történő folytatása.

\section{Apák bevonása}

Az apák tapasztalataink szerint nehezebben vonhatók be, amit már a korábban említett kutatásunk előkészítése során tapasztaltunk. 10 fővel szerettünk volna mélyinterjút készíteni a megkérdezettek nagyobb hányada nem vállalta a közremüködést. „Minek róla beszélni?”, „Nem akarom piszkálni már.” - és egyéb hasonló indokokkal.

A mentorhálózatban mindhárom megyében vannak a Mentorházakkal szorosabb kapcsolatot tartó édesapák. Az első mérföldkő az apáknak szóló mentorképzés volt, ami 2019 
adventjének idején valósult meg. A tematika rugalmasan igazodott a csoportigények és a résztvevők hozott élményeihez, feldolgozási módjaihoz. A szülés körüli élményeik feldolgozása - az anyák megéléseihez hasonlóan - rendkívül hangsúlyos volt. A saját tapasztalatok, élmények megosztása, a sorstársi légkör talán még inkább központi tényező volt, mint az anyáknál. A harmadik napon nagy szerepet kapott az aktív önkéntes tevékenységek tervezése: az édesapák motiváltak voltak a folytatásban és sorstársaik segítésében. A karanténhelyzet ennél a pontnál követelte meg a gyors váltást KÉÁ-tól, és többek közt az apák számára is a motivációjuknak megfelelő lehetőség megtalálását.

\section{Az online átállás tapasztalatai}

Egyetértve más szakemberekkel, fontos leszögeznünk: a karanténhelyzet nemcsak az egyéneknek-családoknak, nemcsak átfogó társadalmi szinten jelent krízist, hanem az ellátásttámogatást nyújtó szolgáltatóknak és igénybevevőiknek is. Ez a helyzet egyben lehetőség is: a tág értelemben vett mentálhigiénés támogatással foglalkozó szolgáltatók új lehetőségeket találhatnak, ami mindkét oldal számára előnyös lehet. Ezek akár a jelen helyzeten túl is megmaradhatnak, szélesítve a kapcsolódás lehetőségeit és a támogatási lehetőségeket. A helyzet megkívánja, hogy az eddigi tartózkodást nyitottsággal, kezdeményezőkészséggel és rugalmassággal kezeljék maguk a szolgáltatók is, és cselekvő módon nyissanak az ementálhigiénés támogatási formák irányába (Wind és mtsai., 2020). Az e-mentálhigiénés lehetőségekről írott áttekintésükben Galea, Merchant és Lurie (2020) az online kapcsolódást biztosító technológiai platformok használatát a szokványos támogatás és kríziskezelés fontos eszközeként említi. Tapasztalataink szerint is hasznos, új utakat és lehetőségeket nyit meg a körültekintően, és a változásokat gyorsan lekövető online átállás. A KÉA mindezek mellett a professzionális és az önsegítő utak megőrzésére is törekedett, az eddigi eredmények alapján sikeresen. Az online átállás technikai-adminisztratív hátterét megfeszített munka árán gyorsan és hatékonyan alakították ki az Alapítvány munkatársai. Itt fontos újból kiemelnünk, hogy tapasztalataink azt igazolják, hogy ebben az esetben is nagyon fontos a gyors reagálás és az online szolgáltatások nyújtásának mihamarabbi biztosítása.

Kifejezetten előnyös a tapasztalatunk a csoportos formákkal kapcsolatosan: több esetben a mentorklubokon és egyéb eseményeken várakozásainkon felüli létszámban jelentek meg a résztvevők. Ebben szerepet játszhatott a karanténhelyzet izoláltsága miatt hangsúlyossá vált kapcsolati igény, illetve az elmúlt 3 év „offline-időszakában” megalapozott jó közösségi kapcsolatok is. Ki kell térnünk az online szomatikus szolgáltatásokra is: a szülőkben megjelent a szorongás, hogy időveszteség történik gyermekük fejlesztésében, ezért motiváltak az online fejlesztésekben.

Az online szolgáltatások elérhetőségében nagy szerepet kapott az online, közösségi médiában végzett intenzív és célzott marketingtevékenység. Fontos azonban, hogy az élő, „személyes-online” kapcsolatok szintén fontos szerepet játszottak ebben. Külön hozadéka az átállásnak, hogy a földrajzi határok jóval kevésbé jelentenek akadályt. Jónéhány esetben nagy távolságból, határon túlról is kapcsolódtak-kapcsolódnak a programokba a koraszülésben érintett szülők. Jellemzően a tapasztalati szakértőként dolgozó önkéntesek és a professzionális szakemberek egyaránt, együttmüködve vannak jelen a programokon.

Néhány fórum rövid leírásával illusztráljuk az átállás tapasztalatait:

Online mentorklubok: megyénként, adott esetben pszichológus bevonásával. Az első alkalmak során a nagy létszám mellett tapasztalható volt az online csoportos beszélgetés jótékony, szorongásoldó hatása, a kezdeti elfogódottság utáni felszabadultság. Ebben 
segített a biztonságot adó moderálás és az átlátható viszonyok is. Külön csoport is létrejött a közösségi médiában, amelyben közel félezer szülő oszthatta meg egymással érzéseit, gondolatait, gyermekeik lefoglalásával, ellátásával kapcsolat ötleteit (amelyek sokszor nagyon hasznosnak bizonyultak).

„Születés Hete” országos programsorozat: szegedi, gyulai, kecskeméti online helyszínein a KÉA által szervezett előadásokat nagy érdeklődés övezte. Az online résztvevők aránya észlelhetően magasabb volt a szokványos helyzetben tapasztaltnál.

„PICurka klubok”: heti rendszerességü tematikus online beszélgetések perinatális témákban. A klub célja az online támogatás, informálás, szakszerű párbeszéd kialakítása. Ezeket az alkalmakat jellemzően professzionális szakemberek és érintett önkéntesek együtt vezetik. Folyamatosan nagy igényt tapasztalunk a várandóstámogatás területén, amely az online térben is megmaradt.

\section{Apák és online átállás}

Az édesapák esetében a KÉA két fő irányban indította el az online közösségi alapú támogatás kiépítését. A már képzést végzett mentor édesapák és a szupermentor között folyamatos volt az online / telefonos kapcsolattartás. Egy csoportos online beszélgetés után vetette fel egy médiaszakemberként dolgozó édesapa, hogy készülhetne egy közös podcast-beszélgetés a jelenlegi helyzetröl. A podcast-készítés mint közös csoportcél jól biztosította a csoport együttmüködését, hozzájárult kohéziójának fennmaradásához. A csoporttal megegyezve kisebb technikai nehézségek árán létre is jött a beszélgetés, amelynek nyersanyagából 47 perces podcast készült. A felvétel elkészítésében az ötletgazda édesapa közbenjárása révén neves színművész és zenekar is közremüködött. Témája a karanténhelyzet, az apaság és az ünnepek voltak (ennek aktualitását az adta, hogy húsvéthoz közel készült). Jelenleg a felvétel letölthetőségének kialakítása és a második podcast elkészítése van folyamatban.

Törekvésünk része a nyitás más édesapák felé is. Külön édesapáknak szóló online csoport indult, melynek első alkalma a PICurka klub keretében valósult meg, a továbbiakban pedig havi rendszerességgel külön eseményként. Az eddigi alkalmak során az apák életének gyakorlati vonatkozásairól esett szó. Tapasztalataink szerint kifejezetten jól müködik a peerjellegű támogatás ebben a körben is. Az eddigi alkalmakon az „,apák képviseletében”, illetve kíváncsiságból, anyák is megjelentek. Ezt a gyakorlatot szeretnénk megtartani - az anyai-apai szerepek közötti párbeszéd mindkét oldalt gazdagítja. Megtörtént, hogy az apák a koraszüléssel kapcsolatos kritikusan nehéz élethelyzetben a párját képviselő édesanyát tudták támogatni azzal, hogy megosztották gondolataikat, érzéseiket férfi-apai szemszögböl.

\section{Összefoglaló gondolatok, reflexiók}

A megalapozottan működő közösség és szolgáltatások tapasztalataink szerint képesek online módon is védettséget biztosítani a koraszülésben érintettek számára. Cselekvőképességük, ágenciájuk aktivizálásával hozzájárul életminőségük fenntartásához társadalmi krízis idején is.

Érdemes általános tapasztalatainkat is összefoglalni. Elsősorban az édesanyák körében jellemző, hogy otthonról is megoldható a kapcsolattartás, így egyszerübb kapcsolódni. Nem kell elmenni sehová, így külön erőt, időt lehet spórolni. Az online program közben könnyebb felállni a monitor mellől és lereagálni a felvetődő helyzeteket a gyermekkel, adott esetben nem 
kell külön gyermekvigyázásról gondoskodni. Sokkal rugalmasabban lehet kapcsolódni, mint személyes megjelenés esetén, pl. séta közben is, telefonon keresztül. Fontos, hogy távolról is részt lehet venni a programokban, amelyek egy része visszanézhető, és ezzel a lehetőséggel jelentős számban élnek is.

1) Az első és legfontosabb tapasztalatunk tehát a bevezető gondolatokkal összhangban az, hogy a közösségi támogatási formák átvihetők az online térbe. Ennek illusztrálására ismét a támogató közösség jellemzőit hívjuk segítségül.

Caplan és Killilea (1976) a támogató csoportosulások több funkcióját is megnevezte, ezek közül áttekintünk néhány, a tanulmány szempontjából jelentős pontot. Mindegyik az online helyzetben történt müködést írja le. Ezek a megállapítások igazak a professzionális és a tapasztalati segítői online tanácsadásokra, fejlesztésekre is.

A világra vonatkozó információk gyüjtése és terjesztése

A karanténhelyzetben érthető módon megnő az információigény, ezt mi is tapasztaltuk. A mentorközösségben főleg a mentorklubok és az online két- vagy néhány személyes kapcsolattartás során sok esetben adtak-kaptak hasznos gyakorlati információkat a tagok. Ilyen például a különféle játékötletek, receptek, szolgáltatások és cikkek elérhetősége.

\section{A problémák megoldásában eligazit és közbenjár, a gyakorlati és konkrét segítség forrása}

Több esetben fordult elö, hogy egészen konkrét élethelyzetekhez kötődő probléma vetődött fel, aminek kapcsán gyorsan és hathatósan sikerült segítséget nyújtani. Különféle cikkek, élelmiszer, egyebek beszerzése, ügyintézésben történő segítségnyújtás és más természetes segítési formák.

\section{A feltöltödés szintere és érzelmi teherbírás , karbantartója”}

$\mathrm{Az}$ önsegítő csoportokban hagyományosan megtapasztalható támogatás, énerőfokozódás jól érzékelhetően jelent meg az online csoportok alkalmával is. A szorongás verbalizálása, annak megtapasztalása, hogy mások is vannak hasonló helyzetben, és a beszélgetés hangulatában bekövetkező oldódás a legtöbb csoport velejárója.

A saját tapasztalataink, szakemberi-tapasztalati szakértői becsléseink alapján a fenti hozadékait látjuk az online átállásnak. Ha teljesebb képet akarunk kapni egy éppen zajló helyzetről, két tényezővel mindenképpen kell még számolnunk: a rizikóval és hátrányokkal, valamint az alkalmazkodás árával.

2) Második tapasztalatunk: a hátrányokat, rizikókat érdemes tudatosítani, ami hozzájárul a sikeres kezelésükhöz.

Úgy érzékeljük, nagy szerep jut a technikának és a technikai értelemben vett minőségi kapcsolatnak a folyamatban. Nehézséget jelent, ha valakinek rossz minőségü internetkapcsolata, eszköze van, mert nagy a kommunikációs veszteség. Így az online elérés csökkenti ugyan a hozzáférés egyenlőtlenségét, de a különbség itt is megjelenik. Erre indokolt elöre felkészülni és a technikai paramétereket, főbb problémákat, megoldási lehetőségeket érthető módon a konkrét találkozót megelőzően ismertetni a résztvevőkkel (pl. e-mailen elküldve). 
A váratlanul előforduló technikai nehézségek, az elektronikus kapcsolat megszakadása, kép- és hanghibák csökkentik a kapcsolatból származó biztonságérzést. Ezekről érdemes elöre és menet közben is beszélni, ami hozzájárulhat a helyzetből adódó frusztráltság csökkentéséhez. Találkozhatunk az online kapcsolattartással, a technikával szembeni idegenkedéssel is. Ebben az esetben sokat segít az előzőleg fennálló jó személyes kapcsolat. Ennek mentén lehet megbeszélni, leginkább kétszemélyes helyzetben a tartózkodás okát.

3) Harmadik tapasztalatunk: az átállásnak ára van, alkalmazkodást követel meg a szakemberektől és az intézménytől is.

A technikai minimumfeltételek manapság, ha sok esetben nem is ideálisak, de nem jelentenek luxust. A megfelelő online platformok megtalálása, a közösségi média kapcsolattartásra és jól menedzselt marketingtevékenységre történő használata, a szakmai sztenderdek újragondolása és online viszonyokra adaptálása mind összetevői a sikeres átállásnak. Mindezek azonban mutatói is annak a fajta szakmai nyitottságnak, rugalmasságnak, alkalmazkodóképességnek, amelyet a klienseinknél is szeretnénk látni. Ebben sokat segít a szakembernek a megfelelő képzettség, a csapatmunka és a korrekt szervezeti viszonyok, így ő maga is megkaphatja a támogatást az alkalmazkodáshoz, amire szüksége van. Ezt követően eredményesebben kereshetjük a mindannyiunkat érintő kérdésre a választ: mennyiben nyit új és tartósan új lehetőségeket a komplex segítő-támogató munkában a jelenlegi helyzet, mit vesz el az eddigiekböl és mit hagy változatlanul.

\section{Irodalom}

American Psychiatric Association (2014). DSM-5 referencia kézikönyv a DSM-5 diagnosztikai kritériumaihoz. Budapest: Oriold és társai.

Arockiasamy, V., Holsti, L. \& Albersheim, S. (2008). Fathers' experiences in the neonatal intensive care unit: A search for control. Pediatrics, 121(2), 215-222.

Aszmann A. (2006). A nő-, anya-, csecsemő- és gyermek-egészségvédelem. In Ádány R. (szerk.), Megelözö orvostan és népegészségtan (pp. 483-484). Budapest: Medicina.

Boszormenyi-Nagy, I., \& Spark, M., G. (2018). Láthatatlan lojalitások. Budapest: Animula.

Caplan, G. \& Killilea, M. (1976). Support systems and mutual help. New York: Grune and Stratton.

Dombi E., Monostori D. \& B. Erdős M. (2019, február 22-23.). Koraszülésben érintett édesanyák narratíváinak vizsgálata a szülés körüli idöszakról: A Veszélyeztetett Várandós Támogató Program kidolgozása (konferenciaelőadás). A Magyar Pre- és Perinatális Pszichológiai és Orvostudományi Társaság XVI. Országos Kongresszusa, Budapest. https://www.mpppot.hu/absztraktok/mpppot-2019-absztraktok.

Erikson, E. H. (1997). Az emberi életciklus. In Bernáth L. \& Solymosi K. (szerk.), Fejlödéslélektani olvasókönyv (pp. 27-41). Budapest: Tertia Kiadó.

Farkas A., Monostori D., \& Rózsavölgyi K. (2020, március 5.). Perinatális PTSD-t átélt nök párjainak párkapcsolati reprezentációi. Krízis, trauma, növekedés- konferencia, Szeged.

Galea, S., Merchant, R. M. \& Lurie, N. (2020). The mental health consequences of COVID-19 and physical distancing. JAMA Internal Medicine, 180(6), 817. https://doi.org/10.1001/jamainternmed.2020.1562

Goldenberg, I. \& Goldenberg, H. (2008). Attekintés a családról. Budapest: Animula.

Hajduska M., (2010). Krízislélektan. Budapest: ELTE Eötvös Kiadó.

Hámori E. (2013). Rizikófaktorok, adaptáció és reziliencia a korai fejlődésben: A koraszülöttség a fejlődési pszichopatológia modelljében. Magyar Pszichológiai Szemle, 68(1), 7-22. 
Hugill, K., Letherby, G., Reid, T. \& Lavender, T. (2013). Experiences of fathers shortly after the birth of their preterm infants. Journal of Obstetric, Gynecologic \& Neonatal Nursing, (42)6, 655663.

Jacobson, G. F. (1979). Crisis-oriented therapy. Psychiatric Clinics of North America, 2(1), 39-54. https://doi.org/10.1016/s0193-953x(18)31023-2.)

Komlósi P. (1997). A család támogató és károsító hatásai a családtagok lelki egészségére. In Gerevich J. (szerk.), Közösségi mentálhigiéné (pp. 13-34). Budapest: Animula.

Kopp M., Székely A. \& Skrabski Á. (2007). Mi magyarázhatja a magyar férfiak idő előtti egészségromlását és halálozási arányait? Polgári Szemle, 3(6).

https://polgariszemle.hu/archivum/34-2007-junius-3-evfolyam-6-szam/191-mi-magyarazhatjaa-magyar-ferfiak-ido-elotti-egeszsegromlasat-es-halalozasi-aranyait

Lindberg, B., Axelsson, K. \& Öhrling, K. (2007). The birth of premature infants: Experiences from the fathers' perspective. Journal of Neonatal Nursing, 13(4), 142-149.

Masterson, S. \& Owen, S. (2006). Mental health service user's social and individual empowerment: Using theories of power to elucidate far-reaching strategies. Journal of Mental Health, 15(1), 19-34. https://doi.org/10.1080/09638230500512714.

McGrath, J. (2001). Building relationships with families in the NICU: Exploring the guarded alliance. Journal of Perinatal and Neonatal Nursing, 15(3), 74-83.

Minuchin, S. (2005). Családok és családterápia. Budapest: Animula.

Monostori D. (2020). „Van élet a koraszülött intenzív ellátás után!”: Koraszülő családok támogatási lehetősége. In Fábián G. \& Hegyesi G. (főszerk.), Budai I., B. Erdős M., Héderné Berta E., Kozma J., Szöllősi G. \& Talyigás K. (szerk.), A tudományos gondolkodás és kutatás szerepe a szociális munkában. Debrecen: Debreceni Tudományegyetem. (Megjelenés alatt.)

NIDCAP (blog). https://nidcap.org/en/

Olshtain-Mann, O. \& Auslander, G. K. (2008). Parents of preterm infants two months after discharge from the hospital: Are they still at (parental) risk? Health \&Social Work, 33(4), 299-308.

Patil, S. (2014). Level of stress and coping strategies seen among parents of neonates. International Journal of Science and Research, 3(4), 579-585.

Szanati D. (2011). A logopédus-egészségpszichológus szerepe a koraszülött gyermekek utánvizsgálatában. Gyógypedagógiai szemle (39)3-4, 188-195.

Van der Pal, S. M., Maguire, C. M., Cessie, S. L., Veen, S., Wit, J. M., Walther, F. J. \& Bruil, J. (2007). Staff opinions regarding the Newborn Individualized Developmental Care and Assessment Program (NIDCAP). Early Human Development, 83(7), 425-432. https://doi.org/10.1016/j.earlhumdev.2007.03.007.

Van der Pal, S., Maguire, C. M., Le Cessie, S., Veen, S., Wit, J. M., Walther, F. J. \& Bruil, J. (2008). Parental stress and child behavior and temperament in the first year after the Newborn Individualized Developmental Care and Assessment Program. Journal of Early Intervention, 30(2), 102-115. https://doi.org/10.1177/1053815107313485.

Vanderveen, A., Bassler, D., Robertson, C. M. T. \& Kirpalani, H. (2009). Early interventions involving parents to improve neurodevelopmental outcomes of premature infants: A meta-analysis. Journal of Perinatology, 29(5), 343-351.

Wind, T. R., Rijkeboer, M., Andersson, G. \& Riper, H. (2020). The COVID-19 pandemic: The "black swan" for mental health care and a turning point for e-health. Internet Interventions, 100317. https://doi.org/10.1016/j.invent.2020.100317.

World Health Organization (2020). Mental health and psychosocial considerations during the COVID19 outbreak.

https://www.who.int/docs/default-source/coronaviruse/mental-health-considerations.pdf

Zhou, X., Snoswell, C. L., Harding, L. E., Bambling, M., Edirippulige, S., Bai, X. \& Smith, A. C. (2020). The role of telehealth in reducing the mental health burden from COVID-19. Telemedicine and e-Health, 26(4), 377-379. https://doi.org/10.1089/tmj.2020.0068 